\title{
U.R. Ananthamurthy's Crusade against Caste: the Text and Context
}

\author{
Virender Pal \\ Assistant Professor of English, University College Kurukshetra. ORCID ID is oooo-ooo3- \\ 3569-1289. Email: p2vicky@gmail.com
}

Received August 15, 2017; Revised December 07, 2017; Accepted December 15, 2017; Published December 25, 2017.

\begin{abstract}
Caste system is a reality in India and the discrimination based on caste is probably the most horrifying truth. Many studies have been conducted on the psychological impact of untouchability on the Shudras, but U.R. Anathamurthy's writings concentrate more on the impact of practising untouchability on the Brahmins. His novels and short stories showcase the impact of practising untouchability on the Brahmins. Brahmins live lives of automatons where their every move and action from birth to death is governed by some precedent of the distant past. They live a life that is sterile and barren. The paper studies the impact of practising caste system on the Brahmins in the writings of U.R. Ananthamurthy.
\end{abstract}

Keywords: caste, Brahmin, oppression, Hinduism, rituals, customs.

Caste system is probably the most discussed and most studied institution of India. It is because this system of oppression is peculiar to the country and has great traditional sanction that has survived till date. Over the centuries, caste system has been scrutinized by the western as well as eastern scholars. Critics have come to a consensus that the institution has proved to be the most durable, most elastic and most resilient. Unlike other traditional institutions like that of joint family that has become obsolete and impractical under the influence of modern industrial revolution and economic system, caste system has survived.

It is important to note that struggle against caste predates many modern religions. In sixth century B.C. Gautama Buddha revolted against "caste tyranny" (Porter, 1895, p. 23). By preaching a new code of conduct he was successful in laying the foundation of a world religion, Buddhism, but he "finally failed" (Porter, 1895, p. 23) in annihilating caste system. In the medieval ages, many bhakti poets, saints and religious leaders like Kabir and Guru Nanak were able to penetrate the impregnable castle of caste system, but their influence on society waned with time and caste system again raised its monster head. In the modern age, it survived the social reformers like Jyotiba Phule, Narayan Swami and socio-political leaders like B.R. Ambedkar. It is an irony that positive discrimination, promoted by these reformers helped sustain the 'caste' as need to reclaim the caste comes with accepting the benefits associated with it under constitutional schedules. In fact, the dilemma is of wanting to have the cake and eating it too. The depressed classes listed as scheduled castes in the Indian Constitution want the segregation to remain as it gives them great privileges in the present administrative system, endorsed by Mandal Commission' ${ }^{1}$. There are legal

(C) AesthetixMS 2016. This Open Access article is published under a Creative Commons Attribution Non-Commercial 4.0 International License (http://creativecommons.org/licenses/by-nc/4.0/), which permits non-commercial re-use, distribution, and reproduction in any medium, provided the original work is properly cited. For citation use the DOI. For commercial re-use, please contact editor@rupkatha.com. 
documents demanding one to declare one's caste, although at the same time, calling someone by his/her caste name could lead to legal proceedings- it is as if the system thrives on open secrets and the depressed sections ignore the strong social subtext of segregation as long as the administrative or legal system serves them. It gives them access to plum jobs, postings and promotions without regard to merit, efforts or achievements. This ease is a requisite but it takes away the incentive to work. The repercussions are visible in social life as the grouse against the regime of positive discrimination as well as those who benefit from it is brewing.

In fact, caste system has been the biggest dividing factor in the subcontinent. It is a ruthless and diabolic system that dehumanizes human beings. One is not known by one's actions and personal traits but every action will hearken to the caste that a person belongs to. This leads to fostering of stereotypes associated with the particular caste or relegation of defiant or nonconforming actions to a rare case, occurrence or exception. Idioms are used to endorse the caste discourse. For instance, if someone from a lower caste does something praiseworthy it may be dismissed as 'panchon ungliya barabar nahi hoti', literally translated as 'the five fingers are not equal' but rest of them are of a kind.

Porter sums up the impact of caste system in the following words:

Caste represents the most memorable, comprehensive and successful attempt ever made by an order to oppress humanity in its own interest. Its enactments broke up the race into many fragments never to be reunited, separating Aryans from other peoples by impassable barriers, permanently fixing their occupations, interests, associations and aspirations. As men were born so they must remain. Their course of life was prescribed, their places after death predetermined. (Porter, 1895, p.25)

Caste still remains a reality not only among Hindus, but also among the Muslims, the Christians and the Sikhs in India. Many people converted to escape the tyranny of caste, but they were able to change only their beliefs; the beliefs of other people about their inferiority remained the same. In other words, caste system became a baggage they could not get rid of, a stigma that remained with them even after converting to other religions:

The conversion of so called low castes to Islam and Christianity in many parts of India, and to sects such as Sikhism and Arya Samaj in Punjab and Western Uttar Pradesh, was often motivated by a desire to shed the odium attached to being low. But the converts found that it was not at all easy to shake off their caste and that, in fact, they carried it with them to new faith or sect. Indian Islam and Christianity both bear the stamp of caste system; this is not to say, however, that the caste system among Indian Christians and Muslims is same as the caste system among the Hindus. (Srinivas, 1996, p. 80)

In fact, the caste system has proved to be the most durable and flexible of the oppressing mechanisms. Its success in sustaining itself against the onslaught of democracy, constitutional indemnity, modern transport and modern education has forced the social scientists to theorize about the origin of this diabolic system, its sustenance and its annihilation.

U.R. Ananthamurthy, one of the most important writers of post-independence India, has been a stringent critic of the system. His writings gain even greater importance as he himself happens to be a Brahmin. His accounts show the response of an enlightened though privileged insider to the system. The novelist was accused of "attacking Brahmanism" (Mukherjee, 2005, p. 82 ) in Samskara. Ananthamurthy's preoccupation with the caste remained an important theme in Bharathipura. In fact, he "critiques and subverts a social system erected on degraded and unexamined cultural-religious foundations" (Raval, 2005, p. 114). There is a continuity in 
Ananthamurthy's writings, where most of his heroes are modern men with progressive thinking and recalcitrant tendencies; the theme of oppression within the caste system and how Brahmin life has become stagnant under the influence of caste system is also recurring.

The best example of this continuity is visible in the novels Samskara and Bharathipura. The connection between the two novels is clear from the presence of river Tunga in both the novels. When one reads these two novels one feels that Bharathipura starts where Samskara ends. In fact, in both the novels Ananthamurthy presents two theories of annihilation of caste. When the first fails, he moves on to another. The setting of both the novels is similar. In both the novels, place of action is located on the banks of river Tunga. While in Durvasapura, in Samskara "The Tunga river flowed close to the backyards of the houses" (1999, p.16), "the Tunga flows by Bharathipura" in the novel of the same name (2010, p. 219).

The issue in both the novels is the same, that is, annihilation of caste, though the methods tried in both the novels are radically different. However, no method proves instrumental in vanquishing the caste. So, though the proposed methods of resistance fail in both the novels, the unwavering thesis statement that emerges from the stories is that annihilation of caste is essential to the development of both the groups: the untouchables and the Brahmins.

While the first novel tries to tackle the issue of caste from a metaphysical point of view, the second novel is more confrontationist. In Samskara, the theory is relatively Brahmin centric, where the author wants Brahmins to change their point of view about the caste system. Naranappa, the anti-hero of the novel, tries to bring out the truth about the caste by becoming recalcitrant. In fact, he is happy to play second fiddle to Praneshacharya, who happens to be a learned Brahmin. In the novel, he is contented to act like a gadfly for Praneshacharya, the Vedic savant, who has the influence to change things. In the process of forcing the Acharya to act, Naranappa becomes anti-Brahmin; he flouts all the rules of pollution and breaks all the codes of behaviour: drinks liquor, eats meat and defiles the holy stone (Samskara, 1999, p. 19). But what his actions fail to accomplish is accomplished by his death. The Acharya changes, but caste remains. In the novel, action is centred more on Brahmins where the novelist tries to explore if the Brahmins can be awakened to the dangers of caste. The shudra males are virtually absent from the action.

In the second novel, Jaggannath seems to be a reincarnation of Naranappa. Acutely aware of the failure of his strategy in the previous birth, Naranappa appears in Bharathipura as a young man with Western education and a new strategy to annihilate caste. In Samskara, Naranappa stays in the background, his radical ideas remain undeveloped and his revolution is confined to himself, but in Bharthipura, Jaggannath openly revolts against the town and the caste system. He takes the help of newspapers to spread the news of his intended revolution and tries to gather support from the like-minded people. He understands the importance of educating the untouchables and mingling with them. For a concise description, he seems to be a radical Gandhian on steroids.

The strategy in the novel also changes. The action shifts to the untouchables where Jaggannatha tries to rouse the untouchable youth against the diabolic system. The novel shows the revision in the strategy of the novelist. In fact, in Bharathipura, Ananthamurthy shows how the politicians of the country have betrayed the oppressed classes. In Samskara, he is hopeful of Congress party playing a major role in annihilating caste and giving rights to the untouchables:

Your texts and rites don't work anymore. The Congress Party is coming to power, you'll have to open up the temples to all the outcastes. (1999, p. 21) 
He is so enthusiastic about the anticipated role of Congress party that "when he heard about the Congress Party here and there, he came to the village and taught the boys the new fashion of Congress uniform" (1999, p.71). But Bharathipura shows that all the hopes that were associated with the Congress were false. What Naranappa hoped about the opening of temples to the untouchables is not accomplished even after the visit of the President of the country (Bharathipura, 2010, p.6). In the novel, Congress appears as a party that has betrayed the hopes of the millions. While the dedicated people like Sripathi Rao have been left out of the party set up, the members of "pro-British Justice party" (2010, p. 46) like Gurappa Gowda are taken in. The Congress party in the second novel appears as a diseased organization that has deceived people. The revised attitude of Ananthamurthy towards Congress shows that the political set up in the country will not do anything to annihilate caste because the consolidation of caste identity works in politicians' favour. That is why Jaggannath decides to take the action by himself. Like Naranappa he does not wait for the things to happen, rather tries to change the town by initiating an action himself.

Though the heroes fail in both the novels, the novels make one thing clear: annihilation of caste is important for Brahmins as well as the untouchables. A lot of studies have been done on the oppression of the untouchables in the caste system. Ananthamurthy, too, is aware of dehumanization of the untouchables. In his "Author's Note" to the translation of Bharathipura, he writes:

If you ask me what is the worst of the Indian civilization, I would say it is untouchability. I can understand slavery- a slave can fight back- but untouchability gets internalized. The victim gradually begins to feel he is untouchable.(2010, p.X)

From an untouchable's point of view caste system is a diabolic system that crushes his humanity and individuality; and turns him into a non-entity. But the perpetrators of this system also suffer. The oppressor also gets oppressed under the irrational laws of the orthodoxy, but in a different way.

The lower castes internalize the inferiority complex, likewise the so-called superior or swarna castes internalize the superiority complex. But this superiority complex does not come without complications. The 'superiors' have to remain circumscribed within an available action arena to maintain their superiority. Only a limited set of action is allowed to them and they have to follow normative professions and hold unquestioned allegiance to the conventional ideology. In the process of maintaining difference between the inferiors and the superiors they become so engrossed that they become slaves to the rituals and rites that differentiate between the two groups. In the past, the difference was underlined through selective access to knowledge and learning especially of the Vedas, but in the contemporary times, the difference is maintained through observing the rituals and by not adopting certain 'lowly' professions traditionally assigned to lower castes. The status of Brahmins as the sole guardians of knowledge and learning has been usurped as contemporary education in India apparently at least is accessible to all and denied to none. So Brahmins try to compensate it by slavish adherence to the rituals, not just them but other privileged castes also invest money and belief in ritual performances to highlight their status. In Ananthamurthy's novels, Brahmins are slaves to the rituals to an extent where they concentrate on nothing except the rituals. The rituals add hardship to their lives and this hard and austere life earns the admiration of other people. In contemporary India, rituals get still greater value when their performance is undertaken by 'lower' castes as means of protest to highlight the point that the 'upper' castes do not have any exclusive rights over rituals. This 
democratization of rituals has not, however, led to a corresponding shattering of the caste system as caste is retained no matter what.

In both the novels, Brahminical life-style encumbered by rituals is "sterile" (Bharathipura, 2010, p. 11). Jagannath is extremely critical of such a life-style because "not a single beautiful thing could be created in these towns where Brahmins and traders lived" (Bharathipura, 2010, p. 10). This sterility and unproductivity can be ended only by annihilation of oppressive caste system. This unproductivity hinders the growth of the whole society. The most serious indictment of unproductivity of Brahmins occurs in Ananthamurthy's short story "Stallion of Sun":

Without destroying the likes of this Venkata, there would be no progress, no electricity, no river dams, no pencillin, no pride, no honour, no joy of sex, no winning a woman, no climax, no flying, no joy of life, no memory, no ecstasy, no bliss. (2008, p.146)

In the story, through the character of Venkata, Ananthamurthy makes it clear that such unproductivity is epidemic and such unproductive people are like malignant tumours inflicting the whole society. They do not produce anything, but their unproductivity is not passive, it actively opposes the production capability of other individuals and the society on the whole. For them modern professions are taboos:

Who induced Garuda's son to run away from home and join army? Naranappa, who else? Praneshacharya had taught the boy the vedic scriptures, but what mattered finally was only Naranappa's word. That fellow was hell-bent on corrupting our young people. (Samskara, 1999, p. 10)

Brahmins in the novels live a life of poverty because the modern professions are thought to be "corrupting." But this poverty has a dehumanizing impact on the males. They become sinners who know every kind of sin: "sins of gluttony, sins of avarice, love of gold" (Samskara, 1999, p. 24).

This unproductivity is a direct result of over-indulgence in the rituals; the rituals that dominate all the aspects of life. Brahmin males have to take care of the rituals in the most private of the places: bathroom. The oppression of rituals demolishes the spirit of human beings as they feel the weight of rituals even while taking bath. Ganesha's father in Bharathipura becomes furious, when he comes to know that his son takes bath without a loincloth: "What're you doing behind the locked door, you demon? Are you bathing without a loincloth like a Muslim?" (2010, p. 240). The rituals dominate all the aspects of life. They hinder a person from touching some people, obstruct them from doing some professions and allow living life only in a certain way. It must be admitted to the credit of the Indian constitution that law against untouchability has made these extreme injunctions outmoded and disused. Because of so many hindrances the Brahmins in the novels cannot enter secular professions as they might get polluted, closing many viable economic avenues. This sterile lifestyle is hidden under the garb of contentment. In fact, Brahmins are parasites in the modern economic system.

In Samskara, Ananthamurthy stresses the point that the ritual purity of the Brahmins and their knowledge of religious texts does not matter as they possess little knowledge of the larger world due to their parochial concerns. According to the novelist, orthodoxy obstructs the development of the world view of the person and does not allow a person to grasp the larger reality. Among the more orthodox sect of Madhava Brahmins, Praneshacharya the "Crest-Jewel of Vedic Learning" (Samskara, 1999, p.6) fails to recognize the symptoms of plague which is killing people in his agrahara. On the other hand, the leader of Smarta Brahmins, Manjayya is quick to recognize it as plague. In the novel, orthodoxy is also directly connected with economic progress. 
The Smarta Brahmins who are not "so crazy about orthodoxy and strict rules" (13) are economically sound. In fact, they are not averse to adopting modern, secular professions and are "experts at running betelnut farms" (1999, p.13). On the other hand, the more orthodox Madhava Brahmins are still dependent on their traditional profession of priesthood. Their orthodoxy does not allow them to move out of their cocoons and explore the outside world and adopt secular profession that is why they are still cursed with poverty. In this sternly governed world, a person who tries to change the things becomes an outcaste or has to commit suicide. Here modernity and modern thoughts are considered deviant; and wherever Brahminism reigns supreme, revolutionaries like Raghav Puranik who goes against the tradition by marrying a widow has to remain confined to the walls of his house (Bharathipura, 2010, p. 96) and the widows who become pregnant (The question, 2008, p. 53) are forced to commit a suicide. It is a world that does not want to change. The revolutionaries are asphyxiated and are forced to bow to tradition.

In the pursuit of "wanting to be considered great" (The Question, p. 59), the life for Brahmins becomes a mechanical, emotionless exercise where a man "prone to anger lust, love, and hatred" is not allowed. All these emotions, greed and avarice remain simmering underneath a stoic cover embellished by caste signs. Brahiminism is present in the novels as an oppressive and exploitative force. Brahmins behave like golems under its influence. They lose the sense of self; the best example is seen in Praneshacharya whose sensuous personality is buried under his outer Brahminical covering. The Brahmin in him forces him to marry an invalid (Samskara, 1999, p.2) to live an abstemious and celibate life so that he can achieve supra-existence or moksha.

In fact, Brahmins live a life of automatons, a life burdened by the past, sanctioned by the holy books. They live a life that is anachronic, out of tune with the modern times, a lifestyle not suited to a fast changing world. The Brahmin world is steeped in the past so nothing new, nothing modern, nothing productive is allowed. The Brahmins in Bharathipura and Samskara must concentrate only on the past to find the solution for the present problems. Life in the past was easy and slow paced where the meaningless rituals and complexities were not questioned, where superiority of Brahmins was taken for granted; it was the time when caste system and untouchability became cemented as nobody objected to the exploitation done by the Brahmins. The Brahmins took advantage of the illiteracy of the common masses and their blind faith in them to declare caste system as divine order:

When caste in an inchoate form issued from overcrowding within the limited areas, spontaneous social segregation and race and religious antagonisms, a priesthood, recently became dominant took advantage of it at once, systematized its restrictions, and declared its laws to be revelation from heaven. (Porter, 1895, p. 23)

Brahmins not only justified the oppression of the masses as divine writ, but they also sought a special status for themselves in addition to being at the top of the hierarchy:

All other castes shall suffer capital punishment, but "no greater sin is known on earth than killing Brahmana.... A Brahmana coming into existence is born as the highest on earth, the lord of all created beings. (Porter, 1895, p. 25)

What comes out in the novels of U.R.Anathamurthy is that Brahiminism is entirely dependent on traditions. Everything that is to be done must have some precedent in the past and precedents often interfere with justice rather than facilitating it. In other words, Brahiminism draws its life blood from the distant past where the Brahmins enjoyed the special status in the society as the priests. This according to Ananthamurthy is a sin: 
Things should die, and be destroyed once their usefulness was past. Such an order would be good, beautiful (The Question, 2008, p. 66)

It is indeed ironic because this static life style goes against the spirit of Hinduism. Hinduism is a dynamic tradition which stresses change. Hinduism stresses that nothing is fixed and stationary and underlines that there is no absolute truth in the world. Rather, truth is incremental, truth keeps on changing, and every new discovery, every new advancement adds to the truth. So the static life and beliefs and rituals of the Brahmins are out of tune with times and Hinduism.

The blind and unquestioning adherence to the past adds unnecessary complexity to the lives of Brahmins. The difference is evident in Samskara. The cremation rituals for Brahmins are very complex where nobody can eat while the dead body is lying in the agrahara. Then there are rules about ascertaining about who is fit to be cremated as a Brahmin. On the other hand, as suggested in the novels, for the shudras life is very simple where there are no rituals to complicate the lives. They just "set fire" to the huts to cremate the dead (Samskara, 1999, p.57). The difference between the lives of shudras and Brahmins is accentuated by the dilemma of cremation of Naranappa among the Brahmins and the relative simplicity of the shudras.

The impact of these complex rituals and the incarceration of Brahmins in the castle of imagined superiority is more visible with the women. In the world of Brahmins, sex is a taboo, a sin which should be used only for procreation and not for pleasure. Brahmin women cannot enjoy sex, they take it as a sin, while the lower caste women do not feel any such inhibitions. The Brahmin women are conditioned to ignore sexual pleasure and to treat it as "an unmitigated disaster" (The Question, 2008, p.53) and long for spiritual attainment. The suppression of sexual desires has a negative impact on them and turn them into asexual objects; they lack sexual appeal and seem to possess no feminine charms. Brahmin women are "short, plump and round" (Samskara, 1999, p. 31) with their "cheek(s) sunken, breast(s) withered, mouth(s) stinking of lentil soup" (Samskara, 1999, p. 37), on the other hand lower caste women like Chandri are the epitomes of feminine charms (Samskara, 1999, p.38). The Brahmin women are like "beautiful marble tomb(s)" (The Question, 2010, p.54) in which all the feelings are buried under the supposed superiority, while lower caste women are like "camphor burning on water" (The Question, 2010, p. 54). There is little doubt that Anathamurthy finds low caste women beautiful because they work hard to earn their living. Lacchi remains beautiful and lively because she indulges in manual labour; on the other hand, Brahmin girl Sharda remains incarcerated in the prison of her Brahminical upbringing(The Question, 2010, p. 54).

The difference between Brahmin girl Sharda and lower caste girl Lachhi is quite obvious:

Lacchi was a fine girl. Very fine indeed; olive -complexioned, straight-nosed, roundhipped and soft, oh, how soft, all over. As she walked through the orchard with a bunch of bananas, one felt like exclaiming in pleasure at the sight of her. She did not walk, she skipped and leaped. Uninhibited laughter, words and gestures dripping with sweetness.Her hands and body playful in a myriad ways. One felt at ease in her presence, convinced that it was no sin to be happy. Her beauty was such, that no one felt there was nothing in the act of making love, which was either disgusting or taboo. She offered herself so generously that one was sure that she could belong to no one else.... She was a genuine and complete female, one hundred percent. Not like Sharda at all. One would not feel that Sharda was naked, even if there was not a stitch on her, she would look like an animal about to be sacrificed. Lacchi appeared nude even when she has clothes on. (The Question, 2008, p. 58) 
The Brahmin females remain aloof to all the feelings. The above description shows that the ritualistic and highly controlled life play havoc with the psychological health of the Brahmin females who are unable to enjoy even the most basic feeling of the human beings. In Ananthamurthy's novels Brahmin women "live only to cook and serve delicious meals" (Bharathipura, 2010, p. 69). If at all they are beautiful, they are unaware of their "maddening beauty" (Bharathipura, 2010, p.70) and they have to commit suicide like Nagamani because their sexuality and feelings do not find any outlet. Their inability to articulate their feelings make them walking corpses and they have to commit suicide (Bharathipura, 2010, p. 72). Due to this aloofness of Brahmin females, Brahmin males seek sexual fulfillment with the prostitutes (Samskara, 1999, p. 134; The Question, 2008, p. 61; Jaratkharu, 2008, p. 174).

All this rigidity is not a part and parcel of Hinduism. In fact, from its inception Hinduism has been grounded in liberal tradition which cannot be "encapsulated in any creedal formulation," a perspective expressed in the Hindu prayer: "May Good thoughts come to us from all sides." Thus Hinduism maintains that truth must be sought from "multiple sources, not dogmatically proclaimed" (Kuiper, 2011, p. 86-87). Even Ananthamurthy seems to convey the same thing in Bharathipura: "It is said in Upanishads, if one seer could see everything, he'd know the absolute truth and there'd be no need for other seers"( Bharathipura, 2010, p.177).

The monolithic interpretation of Hinduism and caste system is flawed. The famous prayer in Brihadaranayaka Upanishad says:

Om asato Maa Sad-Gamaya I

Tamaso Maa Jyotir-Gamaya I

Mrtyor-Maa Amrtam-Gamaya I

Om Shantih Shantih Shantih II ～(www.greenmesg.org)

The above prayer can be translated as:

Om, Lead us from unreality (of transitory existence) to the Reality (of self)

Lead us from Darkness (of Ignorance) to the Light (of spiritual knowledge)

Lead us from the Fear of Death to the Knowledge of Immortality

Om Peace, Peace, Peace.

This prayer definitely shows the willingness of the devotees to gain more knowledge. In other words, the devotee is ready to change his worldview. But on reading Ananthamurthy's novels it seems that Brahmins only chant the mantras (prayers), but do not understand their meaning. They continue to linger in the darkness of pride which is generated by their superiority complex. Vajra Suchikanishad avers that a Brahmin is "one who lives and moves in Brahman. He remains above the pair of opposites. He is unmoved in joy, sorrow, pain and pleasure, pride and prejudice, and has conquered desires and is free from ego-sense" (qtd. in Lahiri). When Brahmins in Anathamurthy's writings are judged in the light of above definitions, nobody qualifies to be a Brahmin. They are scheming fellows, guided by their selfish motives, who know "every kind of sin, sins of gluttony, sins of avarice, love of gold" (Samskara, 1999, p. 24).

In fact, Ananthamurthy's writings show that the Brahmins continue to misinterpret the scriptures to maintain their superior status. The scriptures say that one cannot become Brahmin only by virtue of his birth in a Brahmin family. The criterion is rigid: 
Birth and learning do not make one brahmana. Good conduct alone does. However learned a person may be he will not be a brahmana if he is a slave to bad habits. Even though he may be learned in the four vedas, a man of bad conduct falls to a lower class. (Rajgopalachary, 2009, p. 182)

In fact, the concept of untouchability is against the tenets of Hinduism. In the holy book of Hinduism, Sri Bhagavad Gita, Lord Krishna tells Arjuna:

Man reaches perfection by dedicating his actions to God, who is the source of all being and fills everything. (p. 49)

The important words in the above quote are that God is "the source of all being and fills everything." When God is the source of every living thing and is present in everything then how can a person be rendered untouchable. Treating a person as untouchable means treating God as untouchable. Moreover, when every action is to be dedicated to God then how can a job be menial. So the whole idea of untouchability crumbles and caste system gets demolished on the correct interpretation of the texts. Even Mahabharata makes clear that occupation cannot tell anything about the character of a person:

The occupation may be one he is born to in society or it may have been forced upon him by circumstances or he may have taken it up by choice but what really matters is the spirit of sincerity and faithfulness with which he does his life's work. Vedvyasa emphasizes this great truth by making a scholarly brahmana, who did not know it, learn it from a butcher, who lived it in his humble and despised life. (Rajgopalachary, 2009, p. 165)

In the past there was fluidity in the caste system. The people of other castes could be elevated to the status of Brahmins: "For example a king who did not have enough number of Brahmins for performing an important ceremony did not hesitate to raise a member of lower ranking group to the status of Brahmins" (Baines, 1912, p. 27).

In the current scenario, caste system has become rigid and stagnant as inter-caste marriages are discouraged and even inter-dining is still a taboo in many areas. Of course, the Brahmins have made it static for their selfish motives, but they do not realize the harm it is doing to them. In bringing out the impact of caste system on Brahmins, Anathamurthy has taken some liberties. For example, some of the most beautiful women in post-independence Indian have been Brahmins. The famous actresses like Rekha, Madhuri Dixit, Anushka Sharma, Deepika Padukone, Vidya Balan ("List of Brahmins") are Brahmins. So the description of Brahmin females as ugly and asexual objects seems to be biased.

The Brahmins in modern era are also not averse to joining modern professions. Some of the pioneers in India's software industry have been Brahmins. Even famous social scientist M.N. Srinivas writes that Brahmins are not clinging to their traditional occupations only, he writes about a Karnataka village:

Brahmins and Lingayats are the traditional priestly castes of Rampura. This does not mean that every Brahmin or every Lingayat is actually a priest. In fact, the bulk of Brahmins and Lingayats are engaged primarily in secular occupations while even those who practice priesthood often also engage in subsidiary occupations such as agriculture and money lending. (42)

Thus readers might find that the conditions described in Anathamurthy writings are fictionalized exaggerations, but the message he wants to convey is clear. Caste system not only oppresses the people who are termed as untouchables, but is has a reciprocal effect on the so 
called high caste people also. The high caste people have to live according to the prescribed customs. They cannot enjoy their lives. Their conduct is always open to the scrutiny of the people. In other words, they live a life of a slave to the customs as much as those that are marginalized in the caste system. The caste slavery is even worse because the person is slave to something that is inside him. Thus, it is in the best interest of mankind to dismantle this oppressive structure.

\section{Note:}

i. $\quad$ Mandal Commission was established in 1978, but its recommendations were implemented in 1989 by V.P. Singh government amid sharp criticism and self-immolations.

\section{References:}

Porter, J.H. 1895. Caste in India. American Anthropologist 8.1, 23-30.Web. JSTOR.

Srinivas, M. V. 1996. Village, Caste, Gender and Method. Delhi: Oxford University Press.

Ananth Murthy, U.R.1999. Samskara. Trans. A.K. Ramanujan. New Delhi: Oxford University

---. 2008.Jaratkaru. Trans. Narayan Hegde. In N. Manu Chakravarthy (ed.) U.R. Ananthmurthy Omnibus. Gurgaon: Arvind Kumar Publishers.

---. 2008. "Stallion of Sun." Trans. Narayan Hegde. In N. Manu Chakravarthy (ed.) U.R. Ananthmurthy Omnibus. Gurgaon: Arvind Kumar Publishers.

---.2010. Bharathipura. Trans. Susheela Punitha. Delhi: Oxford University Press.

---. 2010. “Author's Note”. U.R. Ananthamurthy Bharathipura. Trans. Susheela Punitha. New Delhi: Oxford University Press.

Lahri, R. K. Caste System in Hinduism. Web.<http://www.boloji.com>

Rajagopalachari, C.(ed.). 2009. Mahabharata. Mumbai: Bhartiya Vidya Bhavan.

The Bhagavad Gita. Trans. Shri Purohit Swami. Web. <http//:www.holybooks.com>.

Kuiper, Kathleen.2011. The Culture of India. New York: Britannica Educational Publishing.

Mukherjee, Meenakshi.2005. Samskara. In Kailash C. Baral, D. Venkat Rao, Sura P. Rath (ed.).

U.R. Anantha Murthy’s Samskara A Crtical Reader. Delhi: Pencraft International, pp. 82-99.

Raval, Suresh. 2005. Interpreting the Cultural Impasse in Anatha Murthy's Samskara. In Kailash C. Baral, D. Venkat Rao, Sura P. Rath (ed.). U.R. Anantha Murthy's Samskara A Crtical Reader. Delhi: Pencraft International, pp. 114-27.

Baines, A.1912. Ethnography. Strassburg: Trubner Varlag.

List of Brahmins. Web. http://www.wikipedia.org.

Virender Pal Teaches English at University College, Kurukshetra University Kurukshetra. He has done his Ph.D. on Australian Aboriginal literature. He is the author of several academic papers and has completed a UGC sponsored minor project on "Debunking Dalit Stereotypes: A Study of U.R. Ananthamurthy's Novels." His interests include Native literature and Indian literature. His ORCID ID is oooo-0003-3569-1289. 